\title{
Export Credit Insurance - Why Government?
}

\author{
by J. Gill C.B.*
}

\section{Introduction}

In the post-war period there has been a considerable increase in the number of countries with state-backed export credit insurance organizations, in some cases coupled with state involvement in the provision of export finance. The big exporting countries have had such institutions from the early part of this century, and in the last 20 years or so most of the developing countries followed suit, in many cases with technical advice and assistance from the larger countries.

In this context, it should be noted that ECGD has been very active in transferring its technology to the developing world, and many countries have modelled their practices and even their documentation on ECGD procedures.

But every organization is a creature of the economic, commercial, and political circumstances at the time when it was formed, and this in turn may have had a considerable bearing on the extent of the facilities it provides and the ways in which they have been developed. Some have concentrated on insurance, others on finance. Some have collaborated with the private sector, some have not.

\section{ECGD history}

ECGD owes its origin to the aftermath of the first world war when the government wanted to build up the domestic economy and to assist the reconstruction of Europe, notably in the Balkans. Exporting has always been of prime importance to the UK and the intention was to promote a rapid restoration of trade and exports by insuring exporters against bad debts. This was a form of insurance which the commercial market had not traditionally provided on any scale and the Government saw itself as filling a gap in the market place. Early losses were suffered and, after a succession of reviews, it was decided to try to apply the same commercial principles to this form of insurance as to others by seeking maximum spread and range of turnover in the belief that the 'good' business would pay for the minority of 'bad'. The

\footnotetext{
* Chief Executive - Export Credits Guarantee Department, London.
} 
business was built up rapidly before and after the second world war. The range of losses was extended to political risks and from the 50's onwards a close link was forged with export finance through the provision of unconditional guarantees to the banks who financed export credit.

\section{Hindsight}

It is now possible to take a 60 year or so birds eye view of history and to ask oneself what has been achieved by state intervention: whether it is necessary: whether on balance it has been a good thing: and whether the time is coming when the relationship between state and private sector should be changed.

In discussing these issues it is perhaps convenient to distinguish between insurance and finance.

Prima facie, it may seem odd that the government, especially in a country like the UK, needs to concern itself with insurance. The UK has one of the most highly developed and sophisticated international insurance markets in the world, which boasts that it will insure anything from the weather to actresses legs. What then is so special about exports? The vast bulk of exports takes the form of routine continuing sales on relatively short terms. It offers the opportunity of substantial spread. It might reasonably be supposed that on the whole traders want to stay in business, and are therefore likely on balance to meet their obligations. Exports thus seem to be an ideal candidate for a conventional insurance approach.

ECGD's 65 years of existence suggest that the commercial risk (ie the risk of private buyer insolvency or default) may indeed lend itself to conventional actuarial techniques of the kind used in say life or fire insurance. It must however be recognised that even in the better markets of the world, the effect of macro-economic forces, e.g. at a time of credit squeeze, can force many firms at the margin into default or insolvency and ECGD has indeed from time to time met sizeable claims on that account notably in Europe and in North America. This does not necessarily contradict the general principle, but it does call for careful underwriting, monitoring, and pricing of the relevant facilities, including the use of a variety of regulators for insuring doubtful cases. This is the area where, at least conceptually, the private sector ought to be capable of developing and I believe it is doing so, though still in a relatively small way. Perhaps the very existence of a state-backed insurer, exercising quasi-monopoly powers and with unlimited financial backing from the Exchequer, acts as a deterrent to the growth of private insurance.

It is tempting to create a situation in which the state insurers are precluded from this form of short term commercial risk insurance and to leave commercial forces to find their own level. This might be too bold a step to undertake at once, but the way could very well be paved by the state insurer entering into deals with private insurers for mutual reinsurance.

\section{Political risk}

The main problems for private sector insurers have tended to revolve around their perception of the so called political risks ie default by quasi-state buyers of the simple inability or unwillingness of governments to transfer foreign exchange at a time of balance of payments difficulties. This is not the place to enlarge on the problems of third world debt though they 
represent an all too ready reminder of the risks entailed in this kind of insurance. A pure economist might argue that if the political risk is not underwriteable in a commercial sense then the business ought not to be done, because state support for it will amount to a mis-use of real resources and a distortion of trade. Such a view, however respectable, nevertheless ignores the political, social, and economic realities which so many of our governments face. The main problems tend to revolve around the major projects for which there is a shortage of international unvestment capital and where export credit backed by state insurers or providers of finance has been absolutely essential to enable business to proceed.

The world debt problem and the recession have served to concentrate the minds in this area, and a number of governments must be weighing the costs and benefits when they look at the effects on cash-flow and their own government borrowing requirements that the servicing of third world debt has entailed. The assessment is not helped by the increasing number of prestige projects being abandoned or mothballed.

Perhaps this is the moment to look at the financial side of these issues and indeed on the larger question of whether state involvement actually serves to encourage the risks against which it is insuring.

\section{Export finance}

The state may choose to become involved either to ensure the availability of finance for exports, or to influence the cost of such finance. Both these considerations are influenced by the sophistication of the domestic financial market, and limitations on the international movement of capital which may affect the cost and availability of finance in particular countries. It is important therefore that Governments should be very clear about the objective to be served when intervening in the export finance process so that the costs and benefits of such intervention can be properly monitored and measured.

State intervention may take various forms. In some countries, through the setting up of public sector export banks, the process of providing finance and its insurance are brought together in a single operation for a specified range of business. In other cases the Government may simply provide guarantees against bad debt, leaving it to the private market to provide the relevant finance, with the security of the guarantee, which may or may not be unconditional, and which may involve some form of subsidy for the finance, or access to state finance on privileged terms. As in the case of simple insurance, the chosen export financing technique is very much a function of the circumstances prevailing in the country concerned. Even where state-owned export banks are created the finance is not necessarily provided in whole or in part by the Government; it may well be provided by raising capital, effectively at Government guaranteed rates, from the private market.

In the particular case of the UK, for many years the state confined itself to the provision of insurance to exporters, and the exporters could offer that insurance as additional collateral to the private banks who finance them. In the last $20-30$ years however the UK Government has devised a range of direct guarantees to the banking system for particular classes of transactions both short and medium term with the intention of securing priority for export finance in times of a general credit squeeze, or to influence the availibility and cost of funds especially for medium and long term credit. The UK Government has specifically opted out of state banking. The question has been considered on a number of occasions but the prevailing view 
has always been that the interests of the exporting community have been better served by allowing a measure of competition within the private sector whilst providing guarantees from the state against bad debts.

There is one aspect of state intervention which deserves further remark. That is the injection of state aid particularly into long term project credits to enable finance to be provided on soft i.e. aid terms. For many years a clear line was drawn to separate so called commercial credit from aid. But the French Government pioneered the use of mixed credits which other countries have felt forced to match.

\section{Problem of state intervention}

As in many other fields of activity, there are potential benefits and dangers of state intervention in the process or guaranteeing and organizing export credit. The main danger is the removal of normal market disciplines on risk assessment and in the settling of the cost and terms of capital. There is an obvious danger that in removing the normal market discipline, unsound business may be encouraged on excessive terms thus encouraging buyers to over extend themselves and indeed support uneconomic business. There is also a danger, particularly in times of recession and over supply of particular products, that Governments will undulge in a self-destructive credit race. There is no completely satisfactory answer to problems of this kind apart from ensuring that the private market has some stake in the transactions in which the state is involved, and for Governments themselves to seek ways and means of controlling the worst excesses of untrammelled credit competition. International organizations such as the Berne Union, and the Governmental Committees acting under the auspices of the OECD and the Consensus Group are perhaps the best potential disciplines and the UK has been a very strong advocate of such controls and has helped to play a leading part in their development. 